\title{
Az Amszterdami Egészséges Testsúly Program
}

\author{
Amsterdam Healthy Weight Program. IPES-Food. 2017. \\ What makes urban food policy happen? Insights from five case studies. \\ International Panel of Experts on Sustainable Food Systems. \\ www.ipes-food.org
}

Ismerteti: Kaposvári Csilla $\square$

Pécsi Tudományegyetem, Egészségtudományi Kar, Egészségtudományi Doktori Iskola

Beküldve: 2018. 08. 08.

doi: 10.24365/ef.v59i4.346

Kulcsszavak: gyerekkori elhízás, egészséges városi környezet, prevenció, rendszerszintű megközelítés, kollektív felelősség

Keywords: childhood obesity, healthy urban environment, prevention, whole system approach, collective responsibility

„Az emberek azt hiszik, hogy túlsúlyosnak lenni egy abnormális egyéni reakció a normális környezetre. Ez egyáltalán nem igaz! Ez egy normál reakció egy abnormális környezetre." Professor Jaap Seidell, Free University, Amsterdam

Jelen összefoglaló az Amszterdami Egészséges Testsúly Programot (Amsterdam Healthy Weight Program) mutatja be. Az első rész röviden áttekintést nyújt a program főbb vezérelveiről és cselekvési területeiről, amelyek konkrét megvalósítását a „Képzelje el ...” című cikk szemlélteti egészségfejlesztéssel foglalkozó szakemberek elképzelt napi feladatainak megjelenítésén keresztül.

A második rész azokat a tényezőket foglalja össze, amelyeket a megvalósítás sikertényezőiként azonosítanak a forrásként jelölt nemzetközi szakirodalmak. Ezek ismerete azért is fontos, mert segíti a megismételhetőség esélyét.

2012-ben Amszterdamban a gyerekkori túlsúly és elhízás előfordulásának gyakorisága a 19 év alatti gyermekek körében 21\% volt, magasabb, mint az országos átlag. A probléma különösen kiemelkedő volt a migráns, valamint az alacsony jövedelmú és társadalmi státuszú családok gyermekei körében. Felismerve a helyzet társadalmi súlyát, a városvezetés célul tûzte ki, hogy 2033-ra megszünteti a gyerekkori elhízás problémáját Amszterdamban. 2013-ban elindították az Amszterdami Egészséges Testsúly Programot, amely a túlsúly és az elhízás megelőzésére, valamint kezelésére fókuszált a 0-18 éves korú gyermekek és a fiatalok, szüleik, gondozóik, tanáraik körében. Kiemelt célcsoportként tekintettek a már elhízott gyermekekre és a magas kockázatú családokra. A program célul túzte ki, hogy aktívan támogassák a gyermekeket és szülőket a hosszú távon is fenntartható egészséges viselkedésváltozásban.

$\mathrm{Az}$ amszterdami program egy komplex program, amely népegészségügyi, egészségügyi, oktatási, sport, ifjúsági, szegénységgel, közösségépítéssel kapcsolatos, gazdasági, valamint várostervezési beavatkozásokat integrál önkormányzati, gazdasági 
és civil szereplők részvételével. Az elhízás strukturális meghatározóinak megváltoztatását célozza, azaz az egyéni életmódot és értékeket, a mögöttük meghúzódó pszicho-szociális tényezőket, valamint a társas és fizikai környezetet. Továbbá, azokat a lakókörnyezeti és munkafeltételeket, amelyek nehezítik a szülőket abban, hogy biztosítsák a gyerekeiknek az egészséges táplálkozást, a megfelelő fizikai aktivitást és alvást. A program első 5 évében jelentős sikert ért el. A hátrányos helyzetűek között 18\%-kal, míg a teljes gyermekpopulációban 12\%-kal lett alacsonyabb a túlsúlyos és elhízott gyermekek aránya.

\section{A JÖVŐKÉP}

A program kezdetekor és a megvalósítás alatt született gyermekek mindegyike a program végére egészséges testsúllyal fog élni.

\section{A PROGRAM TERVEZÉSÉT ÉS MEGVALÓSITTÁSÁT VEZÉRLŐ ALAPELVEK ÉS ÉRTÉKEK}

- A túlsúly- és elhízásprobléma felszámolása hosszú folyamat, egy generációnyi időt igényel.

- A program tevékenységeinek és beavatkozásainak fenntarthatónak kell lenniük.

- A programban mindenki - minden egyes ember és szakpolitikai terület - számít.

- A gyerekkori elhízás kollektív felelősség.

- A megközelítés evidenciákon alapszik: a program egy tanulási folyamat, alkalmas a valóban múködő beavatkozások azonosítására.

- Döntéseket kell hozni az erőfeszítések fókuszálására.

- A prevenció a legfontosabb, de a ma elő gyerekek helyzete is ugyanolyan fontos.

\section{A PROGRAM SZAKASZAI A REALITÁS ÉS A CÉLOK MÉRHETŐSÉGÉNEK ÉRDEKÉBEN}

- Egészséges testsúly elérése a 0-5 éves gyerek körében 2018-ig.
- Egészséges testsúly elérése a 0-10 éves gyerekek körében 2023-ra.

- Egészséges testsúly minden gyereknek és fiatalnak Amszterdamban 2033-ra.

\section{FŐ CSELEKVÉSI TERÜLETEK/PILLÉREK}

A túlsúly/elhízás elsődleges megelőzése:

- az első 1000 napban (a fogantatástól a 2. születésnapig);

- óvodákban, általános- és középiskolákban;

- lakóközösségekben (kiemelten a 10 leghátrányosabb helyzetúben): célok kitúzése, megvalósítás és teljesülések monitorozása;

- egészséges környezet kialakítása által (várostervezés, élelmiszerkörnyezet révén: beleértve az élelmiszerekre és italokra vonatkozó helyi reklám- és szponzorálási szabályozásokat, a kereskedelmi és vendéglátóipari szereplők részvételét);

- tinédzserek körében;

- speciális igényű gyermekek körében.

A túlsúlyos/elhízott gyerekek esetében:

- az egészséges testsúly visszanyerésében nyújtott támogatás.

Támogató területek:

- tanulási folyamatok megerősítése és kutatás lefolytatása a program támogatására;

- digitális eszközök használata;

- kommunikáció és viselkedésváltoztatás módszertan alkalmazása.

\section{MILYEN TÉNYEZŐK TETTÉK SIKERESSÉ A PROGRAMOT?}

\section{Politikai elköteleződés}

2012-ben Eric van der Burg alpolgármester és a népegészségügyért, egészségügyi ellátásért és sportért felelős városatyának fontos szerepe volt a program elindításában és megvalósításában. Látva a gyerekkori túlsúlyra és elhízásra vonatkozó összehasonlító adatokat Amszterdamban az elhízás témában jártas szakemberekkel együtt- 
múködve -, felismerte, hogy az elhízás jelentős és komplex társadalmi probléma. Megértette, hogy az egyén hibáztatása túlzottan egyszerű megközelítés egy ilyen komplex probléma orvoslására. A kollektív felelősség fontosságát - kiemelten a városvezetés felelősségét - arra alapozta, hogy amikor az emberek nem rendelkeznek megfelelő tudással és képességekkel az egészséges testsúly megtartásához, akkor az (ön)kormányzat felelőssége, hogy ebben támogatást nyújtson. Továbbá megértette azt is, hogy a túlsúlyos vagy elhízott gyerekek családjának gyakran halmozott problémái és speciális igényei vannak, így a gyerekkori elhízás problémájának megoldása nemcsak arról szól, hogy megtanítsák a gyerekeket egészségesen enni és többet mozogni. Ezzel az állásponttal az alpolgármester teljesen szembement a saját pártjával és az akkori országos szakpolitikai iránnyal is, ami az egyéni (szülői) felelősségre helyezte a hangsúlyt, és amelynek szellemében országos kampányokban próbálták a lakosságot meggyőzni, hogy táplálkozzanak egészségesebben, valamint önkéntes vállalásokra buzdították az élelmiszeripart.

Az alpolgármesternek hamar sikerült a legmagasabb helyi politikai prioritások közé emelni a gyerekkori elhízás elleni fellépést és elindult egy programfejlesztési folyamat. Ennek egyik első lépéseként a városvezetés áttekintette, hogy milyen területeken tud beavatkozni. A tágabb jogi kontextus megértéséhez fontos, hogy a 2000-ben elfogadott Holland Népegészségügyi Törvény, valamint a 2015-ös Ifjúságpolitikai Törvény a népegészségügyi feladatokat a helyi önkormányzatok hatáskörébe ruházta át. Ennek eredményeképpen a program elsősorban azokra az intézkedésekre összpontosított, amelyet a helyi önkormányzat irányíthat és befolyásolhat, nem pedig olyan politikákra, mint például, a gyermekeknek szóló reklámok korlátozása, amely továbbra is országos hatáskörbe tartozott. Az önkormányzat azonban még ezeken a területeken is megtette a saját hatáskörében megtehető lépéseket: például, nem engedélyezte a városi sportesemények szponzorálását az egészségtelen élelmiszer- és italgyártóknak; az önkormányzat által kezdeményezett közbeszerzésekben pedig érvényesítette az egészség szempontjait is.
Az alpolgármester meg volt győződve róla, hogy a kialakított program bővíteni fogja a lakosok egészséges választási lehetőségeit. Például, a program előtt az iskolákban lehetett egészségtelen italokat árusító automatákat találni, de nem lehetett könnyen és ingyen csapvizet inni. Ez az iskolai környezet a gyerekeket az egészségtelen alternatíva választása felé kényszerítette. Az automaták kitiltása helyett, az alpolgármester inkább arra fókuszált, hogy több, könnyen hozzáférhető egészséges választási lehetőség legyen elérhető a gyerekek számára. A program nyíltan az egészségtelen életmód mögött meghúzódó komplex társadalmi problémákat célozta meg, úgymint a környezeti feltételek, szegénység, alacsony iskolázottság.

Köszönhetően az alpolgármester elkötelezettségének és aktivitásának, a polgármester és a városatyák testülete hivatalosan is elkötelezték magukat az Amszterdami Egészséges Testsúly Program ambiciózus jövőképe és küldetés-vezérelt szemlélete mellett. A programdokumentumok nyilvános aláírásával 2013-ban elindult a program, amely lehetővé tette azt is, hogy a városvezetés a program 20 éves időtartama alatt teljes mértékben elszámoltatható legyen a kitűzött célok elérésének sikere tekintetében.

\section{Ágazatközi koordináció és finanszírozás}

2012-ben a városvezetés a programfejlesztési folyamat felelőseként a a népegészségügyi terület helyett a Társadalmi Fejlesztés Osztály vezetőjét nevezte ki. Ez a tudatos döntés azt érzékeltette, hogy a gyerekkori elhízás nem csak népegészségügyi jellegű, hanem alapvetően társadalmi probléma. Ezért létrehoztak egy koordinációs munkacsoportot, amelyben az összes releváns ágazat képviselte magát, ez biztosította a program folyamán a városi önkormányzat szervezeti egységei, a szolgáltatások, valamint a lakóközösségek közötti szoros együttmúködést. A koordinációs csoport első feladata az volt, hogy egy hatékony, hosszú távú (20 évre szóló), politikai ciklusoktól független programmodellt dolgozzon ki, támogató szakpolitikákkal és intézkedésekkel a közös felelősségvállalás jegyében. 
A 2 éves stratégiai programfejlesztési időszak, valamint az egyes önkormányzati területek, ágazatok közötti felelősségmegosztás kiépítése után adták csak át a Népegészségügyi Szolgálatnak a programkoordinációt, mivel annak fő szakterülete a konkrét tevékenységek kidolgozása és a monitorozáshoz szükséges indikátorok és adatgyűjtések szervezése és feldolgozása volt.

A program stratégiai fejlesztési időszakában a városi kötelezettségvállalás tudatosan nem tartalmazott finanszírozást. Ehhez az alpolgármester ragaszkodott, aki meg volt győződve arról, hogy a program fenntartható sikerének kulcstényezője többek között a városi önkormányzat különböző egységeiben már meglévő erőforrások összehangolása lesz. A program egyetlen induló költségét a programban résztvevő önkormányzati részlegek által kijelölt projektmenedzserek bértömege képezte. Az, hogy nem rendeltek rögtön az elején költségvetést a programhoz, elég időt adott arra, hogy megtalálják és összekapcsolják a meglévő erőforrásokat és szolgáltatásokat. A program előkészítése így a már futó közösségi, iskolai, önkormányzati és lakónegyedekre, közösségekre vonatkozó kezdeményezések, projektek, továbbá a kapcsolódások feltérképezésével és értékelésével indult.

Például, az amszterdami program épített a már közel 90 éve futó, iskolaorvosok és védőnők által megvalósított gyerekegészségügyi programra. $\mathrm{Az}$ amszterdami program keretén belül a helyi közösségekkel és civil hálózatokkal való együttműködés javítása révén megerősítették az iskolaorvosok és védőnők szerepét. Továbbá, bevonták a Hollandiában 2010 óta már sikeresen futó, az amszterdami programtól kissé eltérő szemléletû „Fiatalok Egészséges Testsúllyal” (Young People at a Healthy Weight - JOGG) nevű gyerekkori egészséges testsúly programot is. A koordinációs munkacsoport szorosan együttmúködött egyéb városi nagyprogrammal is, mint például, a Mozogj Amszterdam, az Amszterdami Szegénységellenes Program vagy a városi Élelmiszerkörnyezet Stratégia. Ez utóbbi eredetileg a városi mezőgazdaságra, a helyi gazdaságra és a környezeti fenntarthatóságra fókuszált, azonban a program óta már az egészséges testsúly is megjelenik benne szempontként. Más intézkedéseket, mint például, a metrómegállókban gyerekeknek szóló egészségtelen ételek/italok reklámozásának tiltását már az amszterdami program keretében hozták meg, mivel az már az átfogó amszterdami egészséges testsúly jövőkép része volt.

„Szeretnénk, hogy az emberek egészséges életmódra váltsanak. Ezt eddig nem igazán tudtuk elképzelni. Az Egészséges Testsúly Stratégia és az Élelmiszer Stratégia megváltoztatta a várostervezés eddigi szempontjait és a saját egészségügyi osztályunk gondolkodását is. A helyzet az, hogy eddig egyáltalán nem gondolkodtunk igy... Mindannyiunk gondolkodásmódjában változás következett be." - Tisztségviselö, Városfejlesztés és Fenntarthatóság Iroda, Amszterdam

Idézet forrása: What Makes Urban Food Policy Happen report, iPES Food, 2017

A városvezetés csak az ágazatok és önkormányzati szervezeti egységek közötti kooperáció és koordináció megteremtése után fogadta el a program költségvetését 2015-ben (évi 2,5 millió Euró). Ezt az összeget a holland kormány egészítette ki plusz forrásokkal egy-egy specifikus projekt vagy cél megvalósítása érdekében. A program folyamán is törekedtek arra, hogy csak olyan tevékenységeket finanszírozzanak, amelyek bizonyítottan hatásosak, ideértve a program által azonosított hiányzó és szükségesnek ítélt szolgáltatásokat. Az ágazatközi koordináció ahhoz is hozzájárult, hogy az egészség szempontja több ágazat napirendjére felkerült, a koordináció megvalósításával a párhuzamosságokat is sikerült kiküszöbölni.

\section{Kollektív tanulási folyamat}

Az esettanulmányok további kulcstényezőként emelik ki, hogy a résztvevők a programot egy közös tanulási folyamatnak tekintették. A program irányelve a tapasztalati tanulás és a tanuláson keresztüli tapasztalás volt. A program szemléletében kezdetektől fogva érvényesült a holland ún. „arany hármas” koncepció, vagyis, az a meggyőződés, hogy a kormánynak, a civil szférának és a tudásközpontoknak (egyetemek, akadémiai szféra) együtt kell dolgozniuk a problémák megoldásában. A koncepció és a tanulási folyamat köti össze a gyakorlatot, a programot, a politikát és a tudományt. Ez az egyes beavatkozások és 
szakpolitikák folyamatos felülvizsgálata által valósulhatott meg.

A program elején két új csapat alakult ennek a folyamatnak a támogatására. Egy egyetemi kutatókból, népegészségügyi és más tudományterületek képviselőiből álló külső szakértői csapat követi az éves eredményeket. Egy belső népegészségügyi szakértői csapat pedig a kimeneti indikátorokat értelmezi negyedéves rendszerességgel. A két csapat együttesen támogatja a bizonyítékok összegzését, az elhízás és a beavatkozások közötti folyamatok megértését, a tanulságok, ajánlások megfogalmazását, valamint irányítják az új beavatkozások kutatási hátterét. A rendszeres monitorozás és értékelés lehetővé tette, hogy az egyeztetéseken keresztül a beavatkozásokat folyamatosan javítsák, vagy szükség esetén új beavatkozásokat indítsanak. Ezt az értékelések során pozitív tapasztalatnak élték meg a résztvevők.

A tanulási folyamat például azt is jelentette, hogy a programot közvetlenül megvalósító szakemberek speciális ismeret- és tudásigényét is ki kellett elégíteni és fejleszteni. A dietetikusok és védőnők táplálkozással kapcsolatos tanulási folyamatát speciális képzésekkel, és egy szakértői digitális platform létrehozásával támogatták, hogy a résztvevő szakemberek könnyen hozzáférhető, autentikus szakmai tartalmak alapján fogalmazhassák meg a célcsoport felé átadott üzeneteket és ismereteket.

\section{A célcsoportok bevonása}

A programmegvalósítás korai szakaszának egyik fontos tanulsága a célcsoportok bevonásának szükségessége volt. Ez részben a közösségi csoportok, a lakosok, vallási és egyéb civil szervezetek aktív részvételét jelentette, kiemelten a lakóközösségek cselekvési pillérben. A programot megvalósító csapat például rendszeresen tartott nyilvános konzultációt a résztvevő közösségekben arra vonatkozóan, hogy megtalálják a legmegfelelőbb és a helyi igényeket figyelembe vevő leghatékonyabb gyakorlatokat, támogassák a közösség által szervezett sikeres kezdeményezéseket az egészségesebb táplálkozás és fizikai aktivitás érdekében. A beavatkozások által megcélzott csoportok megfelelő bevonása azonban az összes többi pillérnél is kiemelten fontos tényezőnek bizonyult.
Például, a programban részvevő iskolákban az egészséges táplálkozási környezet kialakítását célzó „csak csapvíz” beavatkozás bevezetése eleinte a várthoz képest teljesen ellentétes hatást váltott ki. Az eredmények azt mutatták, hogy a gyerekek több cukrot fogyasztottak, mint a beavatkozás előtt. Ez a változás abból eredt, hogy a szülők egy része egészségesebbnek tartotta a gyümölcsleveket a tiszta víznél, ezért iskola után otthon több gyümölcslevet itattak a gyerekekkel, hogy pótolják az iskolai vízivás miatt kiesett cukrot és vitaminokat.

E váratlan negatív eredmény értékelésénél a program arra jutott, hogy a szülőket nem vonták be és tájékoztatták megfelelően az iskolai „csak csapvíz" beavatkozás jelentőségéről és hatásairól. A feladat így a szülők gyümölcslevekkel és a vízivással kapcsolatos attitűdjének és ismereteinek megváltoztatása volt, ami nem bizonyult egyszerü feladatnak. Ebben a témában többek között külön képezték a tanárokat, a szülőknek interaktív színházakat szerveztek az iskolában a problémáról, extra táplálkozási tanácsadókat biztosítottak azokban az iskolákban, ahol ez szükséges volt. Végül így sikerült elérni, hogy a gyerekek cukorfogyasztása csökkenjen.

\section{ÖSSZEFOGLALÁS}

Az amszterdami program integrált, politikai pártokon és ciklusokon átívelő, a teljes rendszer szereplőit mozgósító kezdeményezés. A program alapelvei a társadalmi hatások elérését célozzák, így sok tekintetben a program jóval több, mint a gyerekkori elhízás csökkentése. Sokkal inkább a kultúra megváltoztatása és befektetés egy egészségesebb jövőbe annak érdekében, hogy minden gyereknek biztosítsa a város az optimális mentális, fizikai és érzelmi növekedést.

Az amszterdami program szemlélete holisztikus, amely integrált rendszerszintû megközelítéssel az egészség strukturális meghatározó tényezőit, a társadalmi környezetet célozza meg. Ezáltal teszi könnyebbé az embereknek, hogy egészségesen éljenek, mert szisztematikusan támogatja az egészséges életmód választását egy egészségesebb környezetben. Az amszterdami program emellett a közösségeken alapuló erőfeszítésekre épít, amely 
biztosítja, hogy a program a leginkább érintett gyerekeket érje el. De integrált olyan értelemben is, hogy a prevenció mellett a túlsúlyos és elhízott gyerekek ellátásával is foglalkozik.

Az esettanulmány a városi politikai vezetés elkötelezettségét és szerepét, az önkormányzatok cselekvési hatáskörét biztosító jogszabályi környezetet, a kutatásra és tanulási folyamatra alapozott szakpolitikai- és programtervezést, az integrált, teljes rendszerszintű megközelítést, a célcsoportok bevonását, a következetes monitorozást és folyamatos értékelést emeli ki többek között az eddigi sikerek mögött meghúzódó kulcstényezőkként. Kiemelik még a városi önkormányzaton belüli ágazatközi koordinációs mechanizmus kialakítását és működtetésének kulcsszerepét a program elején, melynek jelentősége megelőzte a programhoz rendelt költségvetés biztosítását. A programhoz rendelt helyi, illetve országos források megléte mellett legalább annyira fontosnak tartják a megvalósítás későbbi fázisában is azt a törekvést, hogy közpénzt hatástalan beavatkozásokra ne költsenek, másrészt a párhuzamos programokat és kiadásokat a rendszeren belül megszüntessék.

\section{1. táblázat: Szereplök és szerepek}

\begin{tabular}{|c|c|}
\hline Alpolgármester & $\begin{array}{l}\text { - a gyerekkori elhízás politikai prioritássá tétele } \\
\text { - a program ösztönzése }\end{array}$ \\
\hline $\begin{array}{l}\text { Főpolgármester és városatyák } \\
\text { testülete }\end{array}$ & $\begin{array}{l}\text { - politikai elkötelezettség és finanszírozás biztosítása } \\
\text { - az összes városi testület és szerv kötelezése arra, hogy járuljanak hozzá az } \\
\text { elhízás ellenes küzdelemhez }\end{array}$ \\
\hline Társadalmi Fejlesztési Osztály & $\begin{array}{l}\text { - a program vezetése a kezdetekkor, amelynek üzenete, hogy az elhízás } \\
\text { nem csak népegészségügyi probléma }\end{array}$ \\
\hline $\begin{array}{l}\text { Cselekvési terület/pillér } \\
\text { munkacsoport }\end{array}$ & $\begin{array}{l}\text { - integrált napi munka a különböző önkormányzati területek és városi } \\
\text { stratégiák között }\end{array}$ \\
\hline $\begin{array}{l}\text { Népegészségügyi Szolgálat } \\
\text { szakértői csoport }\end{array}$ & - a program kimeneteinek és eredményeinek követése \\
\hline Akadémia/egyetemek & $\begin{array}{l}\text { - a program konceptuális modelljének kidolgozásához való hozzájárulás } \\
\text { - szakértői csapatban való részvétel, amely tudományos evidencián és } \\
\text { tapasztalati tanuláson alapuló új tudást generált }\end{array}$ \\
\hline $\begin{array}{l}\text { Sarphati Amsterdam/a város } \\
\text { által alapított kutatóintézet }\end{array}$ & $\begin{array}{l}\text { - a gyerekkori elhízás megelőzését célzó beavatkozások } \\
\text { fenntarthatóságának és hatékonyságának vizsgálata }\end{array}$ \\
\hline $\begin{array}{l}\text { Központi Ellátási Menedzserek } \\
\text { (ifjúsági népegészségügyi } \\
\text { csapat) }\end{array}$ & $\begin{array}{l}\text { - az elhízott gyerekek szüleivel és gondozóikkal való együttmúködés az } \\
\text { ellátás koordinációjának és az egyéni igények megismerésének céljával }\end{array}$ \\
\hline Iskolák/tanárok & $\begin{array}{l}\text { - a program céljainak támogatása } \\
\text { - az egészséges táplálkozással, fizikai aktivitással foglalkozó iskolai program } \\
\text { megvalósítása }\end{array}$ \\
\hline $\begin{array}{l}\text { Elhízott gyerekek szülei, } \\
\text { gondozói }\end{array}$ & $\begin{array}{l}\text { - a program szemléletének érvényesítése az iskolán kívül } \\
\text { - } \text { érdekében } \\
\text { - tudás- és készségfejlesztés az egészséges életmód gyakorlásának } \\
\text { biztosítására a családban, az egyéni igények fényében }\end{array}$ \\
\hline Közösségi csoportok & $\begin{array}{l}\text { - helyi fórumokon való részvétel, hogy a helyi tapasztalatokat és } \\
\text { sajátosságokat a program felé közvetítsék } \\
\text { - döntéshozás a saját egészséges környezetük kialakításával kapcsolatban }\end{array}$ \\
\hline
\end{tabular}

Forrás: Table 3: Key actors and their roles. Amsterdam Healthy Weight Program. IPES-Food. 2017. What makes urban food policy happen? Insights from five case studies. International Panel of Experts on Sustainable Food Systems. www.ipes-food.org 